\title{
Factors Precipitating Hypokalemia in Diabetic Patients: A Cross Sectional Study
}

\author{
Sheikh Salahuddin Ahmed ${ }^{1}$, Fazle Nur ${ }^{2}$, Md. Rahamat Ullah ${ }^{3}$, Abdullah Al Mamun ${ }^{4}$, \\ Md. Aminul Haque Khan ${ }^{5}$
}

Received: February 2, 2014 Accepted: May 20, 2014

\begin{abstract}
Background: Hypokalemia is a very common electrolyte imbalance in diabetic patients which leads to substantial morbidity and mortality. Severe hypokalemia is associated with lifethreatening arrhythmias and sudden cardiac death. There are no adequate studies regarding the incidence and factors precipitating hypokalemia in Bangladeshi diabetic subjects. Objective: The objective of this study was to find out the factors precipitaing hypokalemia in diabetic patients. Materials and Methods: A total 95 admitted diabetic patients with hypokalemia were studied. Specimens were collected from all adult diabetic patients with serum potassium level $<3.5 \mathrm{mmol} / \mathrm{L}$ irrespective of cause of admission. Informations were obtained in a semistructured data collection form and analyzed. Results: Most of the subjects (61.1\%) belonged to the age group of 60 years and above, $31.5 \%$ to the age group 40-59 years and 7.4\% belonged to the age group of 20-39 years. Sixty one (64.2\%) patients were females and 34 (35.8\%) were males. In 63.2\% cases, vomiting was found as a factor causing hypokalemia in the diabetic patients. Other common factors precipitaing hypokalemia were diarrhea (42.1\%), inadequate diet (9.5\%), severe hyperglycemia $(3,2 \%)$, diabetic ketoacidosis (6.3\%) and drugs especially diuretics (18.9\%), bronchodilators (6.3\%) and steroids (5.3\%). The commonest comorbidity associated with diabetes was hypertension. Conclusion: In this study the commonest precipitating factor causing hypokalemia was vomiting. Majority of hypokalemic patients were female and of older age group. When hypokalemia is identified, the underlying precipitating factor should be sought and the disorder treated. Diuretics should be used with caution in the elderly patients having hypertension, a common comorbid condition of diabetes, as these patients are susceptible to develop hypokalemia.
\end{abstract}

Key words: Diabetes mellitus; Electrolyte imbalance; Hypokalemia

J Enam Med Col 2014; 4(3): 145-150

\section{Introduction}

Potassium $\left(\mathrm{K}^{+}\right)$is essential for transmission of nerve impulses, contraction of cardiac muscle, maintenance of intracellular tonicity of skeletal and smooth muscles, and maintenance of normal renal function. Hypokalemia is defined as a serum $\mathrm{K}^{+}$level of $<3.5$ $\mathrm{mmol} / \mathrm{L}(3.5 \mathrm{mEq} / \mathrm{L}) .^{1-3}$ Moderate hypokalemia is a serum $\mathrm{K}^{+}$level of $2.5-3.0 \mathrm{mmol} / \mathrm{L}$, and severe hypokalemia is a level of $<2.5 \mathrm{mmol} / \mathrm{L} .{ }^{1-5}$ Hypokalemia is frequently encountered in clinical practice. It is more common in hospital populations ${ }^{6}$ and is a common electrolyte abnormality in diabetes mellitus (DM). Patients with hypokalemia often have no symptoms, particularly when the disorder is mild (serum $\mathrm{K}^{+}$ 3.0-3.5 mmol/L). ${ }^{1,7,8}$ Muscular weakness, fatigue, and

1. Professor, Department of Medicine, Bangladesh Institute of Health Sciences (BIHS) \& Hospital, Dhaka

2. Consultant, Department of Endocrinology, BIHS \& Hospital, Dhaka

3. Registrar, Department of Medicine, BIHS \& Hospital, Dhaka

4. Medical Officer, Department of Medicine, BIHS \& Hospital, Dhaka

5. Professor, Department of Biochemistry, Enam Medical College, Savar, Dhaka

Correspondence Sheikh Salahuddin Ahmed, Email: drsksalahahmed@yahoo.com 
muscle cramps are frequent complaints in mild to moderate hypokalemia. ${ }^{9}$ Severe hypokalemia may produce life-threatening arrhythmias, flaccid paralysis, hyporeflexia, dyspnea, tetany and rhabdomyolysis. ${ }^{9}$ Transient causes of hypokalemia are due to cell shift, whereas sustained hypokalemia is caused by either inadequate intake or excessive potassium loss. ${ }^{10}$ It is widely believed that elderly patients are more prone to develop hypokalemia than younger patients. ${ }^{4}$

It is well known that the severe hyperglycemia in DM can cause osmotic diuresis leading to dehydration and electrolyte loss, particularly sodium $\left(\mathrm{Na}^{+}\right), \mathrm{K}^{+}$, chloride and magnesium. ${ }^{11-13}$ Dehydration in turn induces secondary hyperaldosteronism that exacerbates $\mathrm{K}^{+}$ loss. ${ }^{3}$ As a result patient with DM may have hypokalemia. Potassium facilitates the function of insulin in the delivery of glucose to cells; when insulin binds to its receptors on the cell membrane, it causes $\mathrm{K}^{+}$ to flow into the cells. In diabetics, excessive use of insulin is associated with hypokalemia; those with low blood glucose and hypokalemia should avoid using insulin. Routine outpatient insulin treatment does not cause significant hypokalemia. However, when administered in large doses, such as for treatment of the non-ketotic hyperosmolar state that sometimes occurs in older diabetics, insulin shifts potassium into cells and can result in marked serum hypokalemia. In diabetic ketoacidosis, hydrogen ion $\left(\mathrm{H}^{+}\right)$is elevated in the blood and the resulting metabolic acidosis forces $\mathrm{H}^{+}$into cells, displacing $\mathrm{K}^{+}$out of the intracellular compartment. Plasma $\mathrm{K}^{+}$may even be raised initially; however, soon after insulin treatment is started there is likely to be a precipitous fall in the plasma $\mathrm{K}^{+}$due to the movement of $\mathrm{K}^{+}$into cells induced by insulin and the patient is prone to develop hypokalemia. The hypokalemia is also due to rapid shift of potassium from the extracellular to the intracellular space secondary to correction of acidosis. Drugs like thiazide or loop diuretics, used for treating comorbid conditions like hypertension in diabetes may also cause hypokalemia. Diabetic nephropathy is one of the complications of DM, which ultimately leads to renal failure and renal failure sometimes may be a cause of hypokalemia among hospitalized diabetic patients. For insulin, there is a feedback system in which insulin secretion is decreased in hypokalemia whereas it is increased in hyperkalemia. ${ }^{14-17}$ Moreover, hypokalemia decreases peripheral insulin sensitivity. Clinical evidence suggests that the hypokalemic effect of thiazide used for the treatment of hypertension is the causative factor in thiazide-associated diabetes mellitus. ${ }^{18}$ Studies have shown that $\mathrm{K}^{+}$infusions improve glucose tolerance by increasing insulin and proinsulin concentrations. ${ }^{19}$

Even mild or moderate hypokalemia increases the risks of morbidity and mortality in patients with cardiovascular disease. ${ }^{14}$ Hypokalemia increases the likelihood of digitalis toxicity. As a result, when hypokalemia is identified, the underlying cause should be sought and the disorder treated. ${ }^{10}$ Data regarding the incidence and influencing factors of hypokalemia in DM in our country are limited. The objectives of this study was (i) to identify the factors precipitating hypokalemia in diabetic patients, (ii) to find out the comorbidities associated with DM that influences hypokalemia and (iii) to assess the socio-demographic status of these patients.

\section{Materials and Methods}

This cross sectional study was conducted in the Department of Medicine in Bangladesh Institute of Health Sciences (BIHS) and Hospital, Dhaka. The study was carried out for 10 months from January to October 2013. The target population was adult diabetic patients and the sample size was 95. Adult male and female patients ( $>18$ years) suffering from DM and identified to have hypokalemia on admission (serum $\mathrm{K}^{+}<3.5$ $\mathrm{mmol} / \mathrm{L}$ ) were included in the study. Patients unwilling to be included in the study, patients with mental illness and pregnant diabetic patients were excluded. Type 1 and Type 2 DM (T2DM) were labeled on the basis of clinical characteristics. For optimum blood sugar control in many nonpregnant adults the American Diabetes Association (ADA) recommends fasting and premeal capillary plasma glucose at 3.9 to $7.2 \mathrm{mmol} / \mathrm{L}$ (70 to $130 \mathrm{mg} / \mathrm{dL}$ ) and the postprandial capillary plasma glucose at $<10 \mathrm{mmol} / \mathrm{L}(<180 \mathrm{mg} / \mathrm{dL}) .{ }^{20}$ The International Diabetes Federation ${ }^{21}$ and $\mathrm{ADA}^{20}$ recommend a target glycosylated hemoglobin (HbA1c) of $<7.0 \%$ in most individuals. However, a higher target $\mathrm{HbA1c}$ of $7.5 \%$ may be more appropriate in older patients with preexisting cardiovascular disease, or those treated with insulin and therefore at risk of hypoglycemia. ${ }^{22}$ As most of the diabetic patients in our study were older with some comorbid conditions, we have considered glycemic control with a bedside capillary blood glucose at $<10 \mathrm{mmol} / \mathrm{L}$ and $\mathrm{HbAlc}$ up to $7.5 \%$ on admission. 
Sampling was made from all diabetic patients with hypokalemia at the time of hospital admission. Semistructured questionnaire and checklist were used as instruments for data collection. All participants were interviewed face to face followed by physical examination. The data collection form included age, sex, history and physical findings, quantity of sodium and potassium in the diet, and medications administered. Clinical events such as presence of diarrhea and vomiting with duration and severity were noted. Special attention was given to the dose and duration of treatment with diuretics, laxatives, digitalis, corticosteroids, insulin, and catecholamines because these drugs are known to influence the handling or distribution of potassium in the body and can contribute to the development of hypokalemia. ${ }^{23}$ Specimens for blood test were collected from the antecubital vein using disposable plastic syringe. Tests included assays for serum $\mathrm{Na}^{+}, \mathrm{K}^{+}$, chloride, bicarbonate, urea, creatinine and magnesium. Blood specimens were also sent to laboratory for $\mathrm{HbAlc}$ estimation. Urine $\mathrm{Na}^{+}$and $\mathrm{K}^{+}$concentrations and $\mathrm{pH}$ were measured. Random blood glucose (RBG) on admission was done by bedside standardized glucometer from finger prick. Bedside readings by glucometer indicated "high" when RBG was $\geqslant 30 \mathrm{mmol} / \mathrm{L}$ which we have considered as severe hyperglycemia in this study. Urine ketone bodies were estimated bedside by reagent strip method. All the necessary informations were recorded in the data collection sheet. Data editing, coding, cleaning, and analysis were done by using the SPSS windows version 16.0 software program.

\section{Results}

The study was carried out among 95 diabetic patients having hypokalemia on admission. Table I shows distribution of patients according to age, sex, residence, education, occupation and economic status. The age range was 28-90 years with mean $59.5 \pm 12.2$ years. Most of the subjects (61.1\%) belonged to the age group of 60 years and above, $31.5 \%$ to the age group $40-59$ years and $7.4 \%$ belonged to the age group of 20-39 years. Total number of males were $34(35.8 \%)$ and females $61(64.2 \%)$. Majority of the patients $(82.1 \%)$ belonged to urban population; the rest belonged to semi-urban $(9.5 \%)$ or rural areas $(8.4 \%)$. Most of them (43.1\%) had junior school certificate (JSC) level of education or less, followed by higher secondary school certificate (HSC) (34.7\%), graduation and above level
$(14.8 \%)$ and no education at all (7.4\%). Most were involved in household work (51.6\%) followed by selfemployment $(28.4 \%)$, government or private service $(11.6 \%)$ and $8.4 \%$ were unemployed/dependent. Financial condition was found average in $59 \%$, good in $26.3 \%$ and below average in $14.7 \%$ of the study subjects.

Table I: Socio-demographic profile of the study subjects $(\mathrm{n}=95)$

\begin{tabular}{|l|c|c|}
\hline Variables & Number & Percentage \\
\hline Age (years) & & \\
\hline $20-39$ & 07 & 7.4 \\
\hline $40-59$ & 30 & 31.5 \\
\hline$\geqslant 60$ & 58 & 61.1 \\
\hline Sex & & \\
\hline Male & 34 & 35.8 \\
\hline Female & 61 & 64.2 \\
\hline Residential area & & \\
\hline Urban & 78 & 82.1 \\
\hline Semi-urban & 09 & 9.5 \\
Rural & 08 & 8.4 \\
\hline Education & & \\
\hline No formal schooling & 07 & 7.4 \\
\hline Up to JSC & 41 & 43.1 \\
\hline Up to HSC & 33 & 34.7 \\
Graduation and above & 14 & 14.8 \\
\hline Occupation & & \\
\hline $\begin{array}{l}\text { Service (government/private) } \\
\text { Self-employment } \\
\text { (business/agriculture) }\end{array}$ & 11 & 11.6 \\
\hline Household work/house wife & 27 & 28.4 \\
\hline Unemployed/dependant & 49 & 51.6 \\
\hline Financial condition & 08 & 8.4 \\
\hline $\begin{array}{l}\text { Average (Tk. 13000-30000/month) } \\
\text { Good (>Tk. 30000/month) }\end{array}$ & 56 & 59.0 \\
\hline Below average (<Tk. 13000/month) & 14 & 26.3 \\
\hline
\end{tabular}

Table II shows sex distribution of hypokalemic patients in elderly $(\geqslant 60$ years) and relatively younger $(<60$ years) age group of patients. Stratification of the hypokalemic patients according to age revealed 58 $(61.1 \%)$ patients fell into the $\geqslant 60$ years group, and 37 $(38.9 \%)$ fell into $<60$ years group. 
Table II: Sex distribution of hypokalemic patients according to age groups ( $\mathrm{n}=95$ )

\begin{tabular}{|l|c|c|}
\hline Variables & Number & Percentage \\
\hline Age $\geqslant \mathbf{6 0}$ years & 58 & 61.1 \\
\hline Males & 17 & 29.3 \\
\hline Females & 41 & 70.7 \\
\hline Age $<\mathbf{6 0}$ years & 37 & 38.9 \\
\hline Males & 17 & 46.0 \\
\hline Females & 20 & 54.0 \\
\hline
\end{tabular}

In our study we have considered hypokalemia when serum $\mathrm{K}^{+}$level was found $<3.5 \mathrm{mmol} / \mathrm{L}$. The lowest value of serum $\mathrm{K}^{+}$in this study was $1.5 \mathrm{mmol} / \mathrm{L}$. The mean value of serum $\mathrm{K}^{+}$level was $2.86 \mathrm{mmol} / \mathrm{L}$ with standard deviation (SD) of $\pm 0.43 \mathrm{mmol} / \mathrm{L}$. Table III shows distribution of the patients having different ranges of serum $\mathrm{K}^{+}$level. Majority of patients $(60.0 \%)$ with hypokalemia had serum $\mathrm{K}^{+}$level ranging from $3.0-3.4 \mathrm{mmol} / \mathrm{L}$ followed by $23.1 \%$ with serum $\mathrm{K}^{+}$ level of $2.5-2.9 \mathrm{mmol} / \mathrm{L}$ and $16.9 \%$ with serum $\mathrm{K}^{+}$ level of $<2.5 \mathrm{mmol} / \mathrm{L}$. Among the study subjects, T2DM was in $94.7 \%$ and T1DM was in 5.3\%.

Table III: Serum potassium concentration of the study subjects $(\mathrm{n}=95)$

\begin{tabular}{|l|c|c|}
\hline Serum $\mathrm{K}^{+}(\mathrm{mmol} / \mathrm{L})$ & Number & Percentage \\
\hline $3.0-3.4$ & 57 & 60.0 \\
$2.5-2.9$ & 22 & 23.1 \\
$<2.5$ & 16 & 16.9 \\
\hline
\end{tabular}

Fig 1 shows the comorbidities in the diabetic patients at the time of hospital admission. About $67.4 \%$ subjects had hypertension, $40.0 \%$ had chronic kidney disease (CKD), $16.8 \%$ had fatty liver, $9.5 \%$ had ischemic heart disease (IHD) and 3.2\% had congestive cardiac failure (CCF).

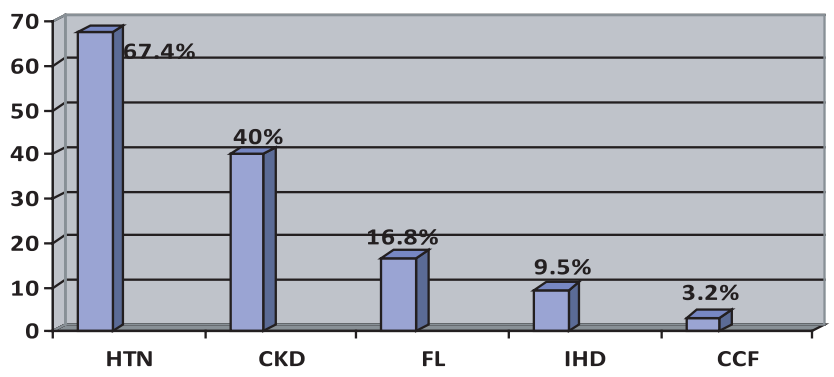

Fig 1. Comorbidities associated with diabetes $(n=95)$ Some patients had multiple responses

HTN, Hypertension; CKD, Chronic kidney disease; FL, Fatty liver; IHD, Ischemic heart disease; CCF, Congestive cardiac failure. Axis values are in percentage.
Fig 2 shows status of diabetes of the study subjects at the time of hospital admission. Diabetes was found uncontrolled in most of the patients (76.8\%).

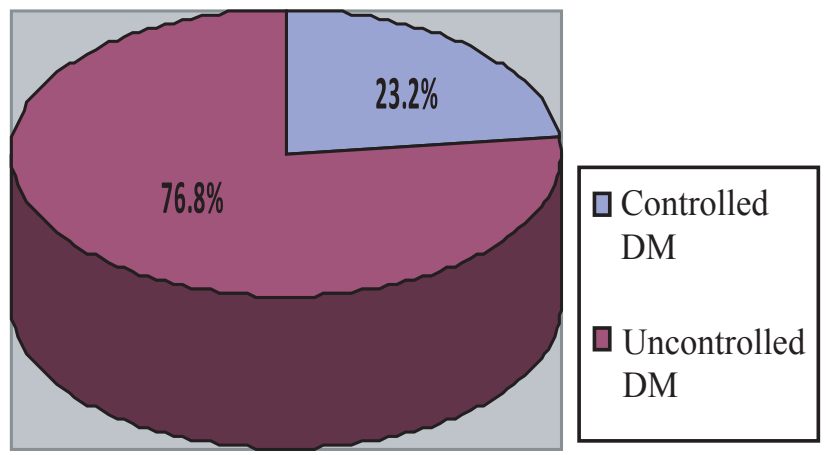

Fig 2. Status of diabetes on admission $(n=95)$

The factors precipitating hypokalemia revealed on hospital admission is shown in Table IV. Most common cause of hypokalemia was vomiting $(63.2 \%)$ followed by diarrhea (42.1\%), diuretics (frusemide and thiazide, $18.9 \%$ ), inadequate $\mathrm{K}^{+}$intake due to severe anorexia or voluntary restriction $(9.5 \%)$, diabetic ketoacidosis (6.3\%) and severe hyperglycemia (3.2\%). About 15.8\% of patients with hypokalemia had hypomagnesemia. CKD was the precipitating cause of hypokalemia in $4.2 \%$ and CLD in $1.1 \%$, cases. No apparent cause of hypokalemia was found in $2.1 \%$ cases. There were no cases of Bartter's, Gitelman's or Liddle's syndromes or of hypokalemic periodic paralysis in this study.

Table IV: Factors precipitating hypokalemia $(n=95)$

\begin{tabular}{|l|c|c|}
\hline Variables & Number* & Percentage* \\
\hline Vomiting & 60 & 63.2 \\
\hline Diarrhea & 40 & 42.1 \\
\hline Hypomagnesemia & 15 & 15.8 \\
\hline Diuretic induced & 18 & 18.9 \\
\hline Inadequate potassium intake & 09 & 9.5 \\
\hline Beta-2 agonists & 06 & 6.3 \\
\hline Corticosteroids & 05 & 5.3 \\
\hline Diabetic ketoacidosis & 06 & 6.3 \\
\hline CKD with edema & 04 & 4.2 \\
\hline Severe hyperglycemia & 03 & 3.2 \\
\hline CLD with edema & 01 & 1.1 \\
\hline No apparent cause & 02 & 2.1 \\
\hline
\end{tabular}

*Multiple responses 


\section{Discussion}

Hypokalemia is common in hospitalized diabetic patients and can be associated with serious adverse consequences. Although older adults have been reported to experience profound weakness from hypokalemia, more commonly there are no symptoms. Instead, low potassium levels are often discovered incidentally during routine blood testing. In the absence of blood testing, low potassium levels may go undetected and drop to the point at which cardiac rhythm disturbances occur.

In this study, most of the hypokalemic patients were of 60 years or older. Another study also revealed that hypokalemia is common in older adults, and increasing age is associated with a marked increase in the incidence of hypokalemia. ${ }^{24}$ In comparison to younger adults, an 80-year-old person has more than three times the risk of having a $\mathrm{K}^{+}$level $<3.0 \mathrm{mmol} / \mathrm{L} .{ }^{8,24,25}$ Of the total hypokalemic subjects in our study $64.2 \%$ were female and $35.8 \%$ were male. Studies have shown that gender also confers risk, with women more likely than men to have a low $\mathrm{K}^{+}$level. ${ }^{8,23-26}$ In one study, mortality of patients with hypokalemia was found more, particularly in females than those having normal $\mathrm{K}^{+}$ level. ${ }^{27} \mathrm{~A}$ retrospective analysis of biochemical data from 58,167 hospital inpatients showed a positive correlation between hypokalemia and both female sex and hospital mortality. ${ }^{26}$

Most of the patients in our study had multiple comorbid conditions of which hypertension was the most common (67.4\%). It was $61 \%$ in a study conducted in Bangladesh Institute of Research and Rehabilitation in Diabetes, Endocrine and Metabolic Disorders (BIRDEM). ${ }^{28}$

The most common precipitating factor for hypokalemia found in our study was vomiting $(63.2 \%)$. In addition to gastrointestinal loss by vomiting there is also excess renal $\mathrm{K}^{+}$loss due to metabolic alkalosis following chloride loss secondary to vomiting. . $^{5}$ However it is widely believed that the most common cause of hypokalemia, especially in developing countries, is gastrointestinal loss from infectious diarrhea. ${ }^{9}$ We have found diarrhea in $42.1 \%$ of hypokalemic patients in our study.

Among the study subjects, $18.9 \%$ were found to use diuretics, $6.3 \%$ beta-2 agonists, and 5.3\% corticosteroids. The study at BIRDEM also revealed vomiting and thiazide diuretics as main precipitating causes of hypokalemia in admitted diabetic subjects. ${ }^{28}$ In a double blind randomized controlled trial, hypertensive men treated with thiazide diuretics who developed serum $\mathrm{K}^{+}$of $\leqslant$had a two-fold increase in

ventricular arrhythmias compared with those with normal serum $\mathrm{K}^{+}$level. ${ }^{29}$ A low serum $\mathrm{K}^{+}$concentration has been found in $10-40 \%$ of patients treated with thiazide diuretics. ${ }^{30}$ A retrospective analysis of biochemical data revealed that drug-related hypokalemia was most commonly seen with diuretics, it was also apparent following use of steroids and insulin in uncontrolled diabetes. ${ }^{26}$

Most of the patients in our study were found to have uncontrolled diabetes on admission (76.8\%). Diabetic ketoacidosis was found in $6.3 \%$ cases and severe hyperglycemia in $3.2 \%$ cases in this study. In severe hyperglycemia, renal glucose loss causes osmotic diuresis, increasing $\mathrm{Na}^{+}$delivery to the distal nephron and promoting $\mathrm{K}^{+}$excretion. With prolonged glycosuria, there is considerable depletion of body stores of $\mathrm{K}^{+}$as well ${ }^{11}$, but hypokalemia is usually mild or absent because insulin deficiency impedes the entry of $\mathrm{K}^{+}$into cells. The underlying $\mathrm{K}^{+}$deficiency is rapidly unmasked when insulin is given, and severe hypokalemia can develop, particularly in patients with diabetic ketoacidosis, unless aggressive replacement of $\mathrm{K}^{+}$ stores is undertaken at the same time.

In this study the commonest precipitating factor causing hypokalemia was vomiting and majority of hypokalemic diabetic patients at the time of hospitalization were females and of older age group. Hypertension was the most common comorbid condition associated with diabetes. Diuretics like thiazide used for treating comorbid conditions like hypertension or congestive cardiac failure in diabetes may result in hypokalemia. Therefore, diuretics should be used with caution in the elderly as these patients are susceptible to develop hypokalemia. Serum electrolytes should be measured in every admitted elderly diabetic patient irrespective of the cause of admission and when hypokalemia is identified, the underlying cause should be sought and the disorder treated since it is an avoidable cause of death. 


\section{References}

1. Oram RA, McDonald TJ, Vaidya B. Investigating hypokalaemia. BMJ 2013; 347: 35-37.

2. Lederer E, Alsauskas ZC, Mackelaite L, Nayak V. Hypokalemia. Medscape. Updated: Jul 11, 2013. Available at: http://emedicine.medscape.com/article/ 242008-overview. Accesed September 2013.

3. Pathology-Harmony-Group. Harmonisation of reference intervals. Clinical Biochemistry Outcomes 2011. Available at: www.pathologyharmony.co.uk/graphics/ Pathology\%20Harmony\%20II\%20\%20for\%20web.pdf. Accesed October 2013.

4. Judge TG. Hypokalemia in the elderly. Gerontol Clin 1968; 10: 102-107.

5. Mandel AK. Hypokalemia \& hyperkalemia. Med Clin N Amer 1997; 81(3): 611-639.

6. Reid A, Jones G, Isles C. Hypokalaemia: common things occur commonly - a retrospective survey. JRSM Short Rep 2012; 3(11): 80.

7. Field MJ, Burnett L, Sullivan DR, Stewart P. Clinical biochemistry and metabolism. In: Colledge NR, Walker BR, Ralston SH (eds). Davidson's principles and practice of medicine. 21st edn. Edinburgh: Churchill Livingstone Elsevier, 2010: 438-441.

8. Gennari FJ. Hypokalemia. N Eng J Med 1998; 339: 451-458.

9. Cho KC. Electrolyte \& acid-base disorders. In: Papadakis MA, McPhee SJ, Rabow MW (eds). Current medical diagnosis \& treatment. 53rd edn. New York: McGraw-Hill, 2014: 844-846.

10. Palmer BF. A physiologic-based approach to the evaluation of a patient with hypokalemia. Am J Kidney Dis 2010; 56(6): 1184-1190.

11. Atchley DW, Loeb RF, Richards DW Jr, Benedict EM, Driscoll ME. On diabetic acidosis: a detailed study of electrolyte balances following the withdrawal and reestablishment of insulin therapy. J Clin Invest 1933; 12: 297-326.

12. Howard RL, Bichet DG, Shrier RW. Hypernatremic polyuric states. In: Seldin D, Giebisch G (eds). The kidney: physiology and pathophysiology. New York: Raven Press, 1991: 1578.

13. DeFronzo RA, Cooke CR, Andres R, Faloona GR, Davis PJ. The effect of insulin on renal handling of sodium, potassium, calcium and phosphate in man. $\mathrm{J}$ Clin Invest 1975; 55: 845-855.

14. Zillich AJ, Garg J, Basu S, Bakris GL, Carter BL. Thiazide diuretics, potassium, and the development of diabetes: a quantitative review. Hypertension 2006; 48: 219-224.
15. Venkat Raman G, Albano JD, Millar JG, Lee HA. Bartter's syndrome and diabetes mellitus. J Intern Med 1990; 228: 525-531.

16. Martinez R, Rietberg B, Skyler J, Oster JR, Perez GO. Effect of hyperkalemia on insulin secretion. Experientia 1991; 47: 270-272.

17. Rowe JW, Tobin JD, Rosa RM, Andres R. Effect of experimental potassium deficiency on glucose and insulin metabolism. Metabolism 1980; 29: 498-502.

18. Shafi T, Appel LJ, Miller III ER, Klag MJ, Parekh RS. Changes in serum potassium mediate thiazide-induced diabetes. Hypertension 2008; 52: 1022-1029.

19. Gorden P, Sherman BM, Simopoulos AP. Glucose intolerance with hypokalemia: an increased proportion of circulating proinsulinlike component. J Clin Endocrinol Metab 1972; 34: 235-240.

20. American Diabetes Association. Standards of medical care in diabetes-2014. Diabetes Care 2014; 37(Suppl 1): S26.

21. International Diabetes Federation, 2012. Clinical Guidelines Task Force Global Guideline for Type 2 Diabetes. Available at: http://www.societate-diabet.ro/pdf/Global-Guideline-for-Type-2Diabetes-IDF-2012.pdf. Accessed January 2014.

22. Pearson ER, McCrimmon RJ. Diabetes mellitus. In: Walker BR, Colledge NR, Ralston SH, Penman ID (eds). Davidson' Principle and Practice of Medicine. 22nd edn. Edinburgh: Churchill Livingstone Elsevier, 2014: 810-811.

23. Steen B. Hypokalemia-clinical spectrum and etiology. Acta Med Scand 1989; 647(Suppl): 61-66.

24. Hawkins RC. Gender and age as risk factors for hypokalemia and hyperkalemia in a multiethnic Asian population. Clinica Chimica Act 2003; 331: 171-172.

25. Wenger NS, Roth CP, Shekelle P. Introduction to the assessing care of vulnerable elders -3 quality indicator measurement set. J Am Geriatr Soc 2007; 55: S247-S252.

26. Paice BJ, Paterson KR, Onyanga-Omara F, Donnelly T, Gray JMB, Lawson DH. Record linkage study of hypokalemia in hospitalized patients. Postgrad Med J 1986; 62: 187-191.

27. Lawson DH, Henry DA, Lowe JM, Gray JM, Morgan HG. Severe hypokalemia in hospitalized patients. Arch Inter Med 1979; 139(9): 978-980.

28. Haque H, Amin MG, Uddin KN, Ahmed JU, Ahmed AKMS, Rahim MA et al. Pattern of electrolyte imbalance in hospitalized patients: experience in tertiary care hospital. Birdem Med J 2012; 2(1): 14-18.

29. Siegel D, Hulley SB, Black DM, Cheitlin MD, Sebastian A, Seeley DG et al. Diuretics, serum and intracellular electrolyte levels, and ventricular arrhythmias in hypertensive men. JAMA 1992; 267: 1083-1089.

30. Schulman M, Narins RG. Hypokalemia and cardiovascular disease. Am J Cardiol 1990; 65: 4E-9E. 